\title{
Implementasi Model Pembelajaran Kooperatif Tipe Think Pear Share (TPS) untuk Meningkatkan Aktivitas dan Hasil Belajar Teknik Dasar Chest Pass Permainan Bola Basket
}

\author{
Brillyan Haba Pau \\ Jurusan Pendidikan Jasmani Kesehatan Olahraga dan Rekreasi, Universitas Pendidikan Ganesha, Singaraja, Indonesia
}

\section{A R T I C L E I N F O Article history: \\ Received 19 November 2017 \\ Received in revised form \\ 6 Januari 2018 \\ Accepted 12 Januari 2018}

Available online 20

Februari 2018

Kata Kunci:

Pembelajaran

Kooperatif Tipe TPS,

Aktivitas Belajar, Hasil Belajar, Chest

Pass Bola Basket.

Keywords:

TPS Type

Coopeartive

Learning, Learning

Activity, Learning

Achievement, Chest

Pass in Basket Ball.

\begin{abstract}
A B S T R A K
Penelitian ini bertujuan untuk meningkatkan aktivitas dan hasil belajar teknik dasar chest pass bola basket. Penelitian ini merupakan penelitian tindakan kelas, yaitu guru sebagai peneliti. Penelitian tindakan kelas ini dilaksanakan dalam dua siklus. Subjek penelitian yaitu siswa kelas XI XI TN B SMK Negeri 1 Singaraja tahun pelajaran 2017/2018, yang berjumlah 32 siswa dengan rincian 22 siswa putri dan 10 siswa putra. Data dianalisis menggunakan analisis statistik deskriptif. Hasil analisis data hasil penelitian didapatkan aktivitas belajar teknik chest pass bola basket mengalami peningkatan $1.4 \%$ pada observasi awal ke siklus I. Kemudian meningkat sebesar $0.9 \%$ dari siklus I ke siklus II. Dan meningkat sebesar $2.3 \%$ dari observasi awal ke siklus II. Disimpulkan bahwa aktivitas dan hasil belajar chest pass bola basket meningkat melalui penerapan model pembelajaran kooperatif tipe TPS pada siswa kelas XI TN B SMK Negeri 1 Singaraja tahun pelajaran 2017/2018. Peneliti menyarankan agar guru PJOK menggunakan model pembelajaran tipe TPS karena dapat meningkatkan aktivitas dan hasil belajar teknik dasar chest pass bola basket.
\end{abstract}

A B S T R A C T

This study was aimed increasing learnig activity and learning achievement in basic technique in chest pass in basket ball in the XI TN $B$ at SMK Negeri 1 Singaraja in school year 2017/2018. This tudy was a classroom action research in which the teacher was the researcher. This classroom action research was conducted in 2 cycles. The subjects were the students of class XI TN B at SMK Negeri 1 Singaraja in the school year 2017/2018 with the total number of 32 students, 22 females and 10 males. The data were analyzed using descriptive statistical analysis. Then, it increased by $22.2 \%$ from the first cycle to the second cicle, and increase by $77.8 \%$ from preliminary observation to second cycle. It can be concluded that activity and learning achievement in chest pass in basket ball increased through the application of TPS type cooperative laerning model to the students of class XI TN B at SMK 1 Singaraja in the school year 2017/2018 the researcher suggested that the teachers of Physical Education Sport and Health use TPS type learning model because it can increase activity and learning achievement in the basic technique of chest pass in basket ball. 


\section{Pendahuluan}

Dalam isi pembukaan UndangUndang Dasar 1945 terdapat sepenggal kalimat yang berbunyi "ikut mencerdaskan kehidupan bangsa dan ikut melaksanakan ketertiban dunia". Untuk mencerdaskan kehidupan suatu bangsa, terlebih lagi individu-individu yang ada di dalamnya, yang merupakan roda penggerak dari suatu bangsa maka pendidikan adalah hal mutlak yang diperlukan. Pendidikan sekarang ini bukanlah suatu barang langka dan mahal yang hanya dapat dirasakan oleh orang-orang yang mampu. Namun, kini pendidikan bagaikan sebuah keharusan atau kebutuhan inti setiap orang disamping makanan. Menurut UUD 1945 Nomor 20 tahun 2003 tentang Sistem Pendidikan Nasional disebutkan bahwa Pendidikan adalah usaha sadar dan terencana untuk mewujudkan suasana belajar dan proses pembelajaran agar peserta didik secara aktif mengembangkan potensi dirinya untuk memiliki kekuatan spiritual keagamaan, pengendalian diri, kepribadian, kecerdasan, akhlak mulia, serta keterampilan yang diperlukan dirinya, masyarakat, bangsa dan negara. Pendidikan tidak hanya didapat di lembaga khusus yang menangani pendidikan namun juga di rumah, dimana peserta didik atau siswa menghabiskan waktunya lebih lama (Winantara, 2017). Pada masa yang telah lalu, sebelum lembaga pendidikan formal didirikan, pendidikan hanya diberikan oleh orang tua kepada anaknya. Isi dari pendidikan yang diberikanpun hanyalah pendidikan ahlak, agama, budi pekerti dan hal-hal yang berguna bagi kehidupannya.

Pendidikan yang sejati adalah pendidikan yang memanusiakan manusia, dalam arti pendidikan membuat atau membentuk karakter manusia yang sesungguhnya. Untuk itu diperlukan berbagai komponen pendukung dalam pendidikan untuk menciptakan generasi penerus bangsa yang mampu bersaing di dunia global diera-era berikutnya. Dalam pelaksanaannya, guru menjadi salah satu ujung tombak dalam mengeksekusi kegiatan-kegiatan yang dapat memajukan pendidikan nasional. Guru yang menjadi ujung tombak pelaksanaan pendidikan nasional haruslah professional. Kurniasih dan Berlin Sani (2016) menyatakan "Guru professional adalah semua orang yang mempunyai kewanangan serta bertanggung jawab tentang pendidikan anak didiknya, baik secara individual atau klasikal, di sekolah atau di luar sekolah".

Mutu pendidikan merupakan bahan pertimbangan yang selalu menarik dibicarakan tidak hanya oleh pakar pendidikan tetapi juga oleh masyarakat luas. Untuk mengembalikan fungsi pendidikan kearah yang diharapkan, kita harus menciptakan atmosfer pembelajaran yang dapat terintegrasi antara model pembelajaran dengan kurikulum berbasis kompetensi pada pengembangan pendidikan karakter (Widiana, 2017). Terlebihnya lagi pendidikan jasmani olahraga dan kesehatan (PJOK), karena PJOK merupakan sebuah mata pelajaran akademik atau aspek dalam proses pendidikan yang berkenaan dengan perkembangan kemampuan gerak individu serta berhubungan langsung dengan respon mental dan sosial. Guru harus dapat mengajarkan berbagai keterampilan gerak dasar, teknik dan strategi permainan/olahraga, internalisasi nilai-nilai (sportifitas, jujur, kerjasama, dan lain-lain) dari pembiasaan pola hidup sehat. Belajar sebagai konsep mendapatkan pengetahuan dalam praktetknya banyak dianut. "Belajar adalah perubahan disposisi atau kemampuan yang dicapai seseorang melalui aktivitas. Perubahan disposisi tersebut bukan diperoleh langsung dari proses pertumbuhan seseorang secara alamiah" (Suprijono, 2009:2). Disamping itu, proses belajar mengajar (pembelajaran) yang ditempuh pendidikan dan peserta didik juga harus mendapat perhatian dalam penilaian ini (Widiana, 2016).

Tidak terkecuali dalam pendidikan jasmani, olahraga, dan kesehatan (Penjasorkes). Jaya (2014) menyatakan "Penjasorkes merupakan bagian integral dari pendidikan secara keseluruhan, yang bertujuan untuk mengembangkan aspek kebugaran jasmani, keterampilan gerak, keterampilan berpikir kritis, keterampilan sosial, penalaran, stabilitas emosional, tindakan moral, aspek pola hidup sehat dan pengenalan lingkungan bersih melalui aktivitas jasmani, olahraga dan kesehatan terpilih yang direncanakan secara sistematis dalam rangka mencapai tujuan pendidikan nasional". Proses pembelajaran penjasorkes merupakan proses pembelajaran melalui aktivitas jasmani yang didesain untuk meningkatkan kebugaran jasmani, mengembangkan keterampilan motorik, pengetahuan dan perilaku hidup sehat dan aktif, sikap sportif, dan kecerdasan emosi. Salah satu materi dalam pembelajaran penjasorkes adalah chest pass dalam permainan bola basket (Budiarta, 2014).

Berdasarkan observasi awal yang peneliti lakukan di SMK Negeri 1 Singaraja pada hari Kamis, tangga 18 September 2017 yang bertempat di Lapangan SMK Negeri 1 Singaraja, pada materi teknik chest pass bola basket, hal yang sama juga dilakukan oleh guru mata pelajaran PJOK di kelas XI TN B SMK Negeri 1 Singaraja berjumlah 32 orang dalam materi keterampilan gerak chest pass dalam permainan bola basket. Setelah meminta peserta didik melakukan pemanasan, guru memberikan materi secara lisan dengan metode ceramah. Kemudian guru memberikan contoh secara langsung yang dilanjutkan dengan latihan dibawah pengawasan guru. Dengan langkah-langkah mengajar seperti ini ditemukan bahwa persentase aktivitas dan hasil belajar peserta didik kelas SMK Negeri 1 Singaraja pada materi keterampilan gerak 
chest pass dalam permainan bola baket masih tergolong kurang aktif. Kondisi ini dimungkinkan karena tenaga yang diperlukan untuk melakukan lemparan chest pass dari pemain kurang besar. Keberhasilan melakukan lemparan chest pass dalam bola basket selain ditentukan oleh penguasaan teknik dasar yang baik juga dipengaruhi oleh kemampuan pemain dalam mengkoordinasikan komponen-komponen kondisi fisik yang diperlukan dalam melakukan chest pass (Oktavianto, 2012). Selain itu hal lain yang melatarbelkanginya adalah tidak terpenuhinya aspek aktivitas belajar sehingga berdampak pada hasil belajar peserta didik yang belum memenuhi standar ketuntasan belajar. Dominasi guru dalam proses pembelajaran masih terlihat, sehingga menyebabkan peserta didik lebih banyak tidak berkonsentrasi serta banyak peserta didik yang berbincang-bincang dengan teman ketika guru menjelaskan maupun mendemonstrasikan gerakan, akibat dari proses pembelajaran yang kurang menarik.

Dilihat dari persentase aktivitas keterampilan gerak chest pass dalam permainan bola basket yang terdiri dari visual, lisan, mendengarkan, metrik, mental dan emosional sebagai berikut: peserta didik yang memperoleh nilai sangat aktif 10 orang (31.2\%) , aktif sebanyak 16 orang (50\%), cukup aktif sebanyak 10 orang (35\%), kurang aktif sebanyak 6 orang (18.8\%) dan siswa dalam kategori sangat kurang aktif tidak ada. Sehingga aktivitas belajar peserta didik secara klasikal di SMK Negeri 1 Singaraja baru terpenuhi sebanyak 6,25, angka ini berada pada kriteria $5 \leq \bar{X}<7$ dengan kategori cukup aktif dilihat dari pedoman penggolongan aktivitas belajar, sehingga aktivitas belajar peserta didik dikatakan belum berhasil. Aktivitas belajar peserta didik dikatakan berhasil minimal berada pada kategori aktif dengan criteria $7 \leq \bar{X}<9$. Maka dari itu, aktivitas belajar peserta didik masih perlu dilakukan perbaikan, sehingga aktivitas belajar peserta didik akan lebih meningkat.

Dengan menganalisa data hasil belajar peserta didik secara keseluruhan terlihat hasil belajar masih tergolong rendah dan kurang, sehingga belum memenuhi Kriteria Ketuntasan Minimal (KKM) sekolah yaitu 78.

Dilihat dari uraian di atas penulis akan mencoba memberikan salah satu alternatif pemecahan masalah yaitu dengan menerapkan model pembelajaran kooperatif tipe TPS. Kooperatif berasal dari bahasa Inggris yaitu cooperative yang artinya kerjasama. Menurut Made Wena (2009), pemelajaran kooperatif adalah sistem pembelajaran yang berusaha memanfaatkan teman sejawat (siswa lain) sebagai sumber belajar disamping guru dan sumber belajar lainnya. Pembelajaran kooperatif adalah pendekatan pembelajaran yang berfokus pada penggunaan kelompok kecil siswa untuk bekerja sama dalam memaksimalkan kondisi belajar untuk mencapai tujuan belajar (Junaedi, 2008). Pembelajaran kooperatif digunakan untuk mewujudkan kegiatan belajar mengajar yang berpusat pada siswa (student oriented), terutama untuk mengatasi permasalahan yang ditemukan guru dalam mengaktifkan siswa yang tidak dapat bekerja sama dengan orang lain, siswa yang agresif dan tidak peduli orang lain (Ni'mah, 2014). Think "berfikir" pair "berpasangan" dan share "berbagi" (Widiastuti dan Ali, tt: 274). Sedangkan menurut Arends thinkpair-share atau berfikir-berpasanganberbagi merupakan jenis pembelajaran kooperatif yang diracang untuk mempengaruhipola interaksi siswa (Trianto, 2009). Model pembelajaran kooperatif tipe Think-Pair-Share (TPS) memberi kesempatan lebih kepada siswa untuk bekerja sendiri sekaligus bekerja sama dengan teman lainnya (Thobroni dan Mustafa, 2011). Kelemahannya menurut Basri (dalam Thobroni dan Mustafa, 2011), kelemahan Think-Pair- Share (TPS) antara lain: a) Memerlukan koordinasi secara bersamaan dari berbagai aktivitas, b) Memerlukan perhatian khusus dalam penggunaan rung kelas. c) Peralihan dari seluruh kelas ke kelompok kecil dapat menyita waktu pengajaran yang berharga. Untuk itu, guru harus membuat perencanaan yang seksama sehingga dapat meminimalkan jumlah waktu yang terbuang. Think Pair Share (TPS) adalah pembelajaran kooperatif yang menggunakan struktur kelompok untuk mengembangkan kemampuan berpikir, berpasangan, dan berbagi yang memberikan kesempatan bagi siswa untuk mengembangkan kemampuan berpikir (Kunandar, 2010 \& Trianto, 2011). Tujuan dari pembelajaran kooperatif tipe Think Pair Share (TPS) yaitu untuk meningkatkan penguasaan akademik, mengajarkan keterampilan sosial dan membantu siswa untuk dapat berpikir kritis, serta meningkatkan pemahaman siswa dalam memahami konsep-konsep pembelajaran (Rusman, 2012). Model pembelajaran kooperatif tipe think pair share (TPS) dianggap dapat memberikan ruang belajar sesuai dengan tuntutan diterapkan dalam pembelajaran (Tawil, 2014). Model Pembelajaran Kooperatif Tipe TPS adalah jenis pembelajaran kooperatif yang efektif untuk membuat variasi suasana pola diskusi kelas. Dengan asumsi bahwa semua resitasi atau diskusi membutuhkan pengetahuan untuk mengendalikan kelas secara keseluruhan dan memberi siswa untuk lebih banyak berpikir, untuk merespon dan saling membantu (Trianto, 2010).TPS adalah jenis pembelajaran kooperatif yang dirancang untuk memengaruhi pola interaksi siswa (Trianto, 2010). Kurniasih dan Berlin Sani (2016) menyatakan bahwa "Model pembelajaran think-pair share (TPS) atau berpikir berpasangan berbagi adalah jenis pembelajaran kooperatif yang dirancang untuk mempengaruhi pola interaksi siswa. Model ini dikembangkan pertama kali oleh Frang Lyman dan Koleganya di universitas 
Maryland". Prosedur yang digunakan dalam TPS dapat memberikan siswa lebih banyak waktu berpikir, untuk merespon dan saling bantu satu sama lain. Dengan metode ini siswa dilatih untuk mengutarakan pendapat dan menghargai pendapat orang lain dengan tetap mengacu kepada materi pembelajaran. Adapun keunggulan dari model pembelajaran kooperatif tipe TPS yaitu melibatkan semua peserta didik secara langsung dalam KBM, setiap peserta didik dapat menguji tingkat pengetahuan dan penguasaan bahan pelajaran masing-masing, dapat menumbuhkan dan mengembangkan sikap berfikir, dapat memperoleh kepercayaan dan kemampuan berfikir serta dapat menunjang sikap-sikap sosial dan sikap demokratis para peserta didik.

Berdasarkan latar belakang yang diuraikan di atas, maka diadakan sebuah penelitian dengan judul Implementasi Model Pembelajaran Kooperatif Tipe Think Pear Share (TPS) untuk Meningkatkan Aktivitas dan Hasil Belajar Teknik Dasar Chest Pass Permainan Bola Basket. Dalam model pembelajaran kooperatif siswa dibentuk menjadi kelompok-kelompok kecil yang terdiri dari empat sampai lima orang untuk bekerjasama dalam menguasai materi yang diberikan oleh guru. Adapun pengetian pembelajaran kooperatif menurut Slavin (dalam Tukiran, 2011) adalah "pembelajaran yang dilakukan secara berkelompok, siswa dalam satu kelas dijadikan kelompok-kelompok kecil yang terdiri dari 4 sampai 5 orang untuk memahami konsep yang difasilitasi guru". Model pembelajaran kooperatif adalah suatu pembelajaran melalui pembentukan kelompok-kelompok kecil dalam kelas. Artzt and Newman (dalam Trianto, 2014) menyatakan bahwa "dalam dalam belajar kooperatif siswa belajar bersama sebagai suatu tim dalam menyelesaikan tugas kelompok untuk mencapai tujuan bersama”. Jadi setiap anggota kelompok memiliki tanggung jawab yang sama untuk keberhasilan kelompoknya. Selama pembelajaran kooperatif siswa tetap tinggal dalam kelompoknya selama beberapa kali pertemuan. Mereka diajarkan keterampilan khusus agar dapat bekerja sama dengan baik di dalam kelompoknya seperti menjadi pendengar yang aktif, memberikan penjelasan kepada teman satu kelompok dengan baik dan berdiskusi. Dalam pembelajaran kooperatif belajar belum selesai apabila ada salah satu kelompok yang belum menguasai materi. Isjoni, (2013) menyatakan "pembelajaran kooperatif adalah suatu model pembelajaran yang saat ini banyak digunakan untuk mewujudkan kegiatan belajar mengajar yang berpusat pada sisiwa (student oriented), terutama untuk mengatasi permasalahan yang ditemukan guru dalam mengaktifkan siswa, yang tidak dapat bekerja sama dengan orang lain, siswa yang agresif dan tidak peduli pada yang lain. Menurut Eggen and Kauchak (dalam Trianto, 2014) menyatakan "pembelajaran kooperatif merupakan suatu kelompok strategi pengajaran yang melibatkan siswa bekerja secara berkolaborasi untuk mencapai tujuan bersama". Dengan pembelajaran kooperatif diharapkan siswa mampu bekerja sama untuk belajar dan bertanggung jawab pada kemajuan belajar temannya. Oleh karena itu, dalam pembelajaran kooperatif siswa harus bisa menyingkirkan rasa egoisnya untuk bisa memahami materi pembelajaran sendiri. Rasa solidaritas dikalangan siswa dapat dikembangkan sehingga kelak akan muncul generasi baru yang memiliki prestasi akademik yang cemerlang dan memiliki solidaritas yang kuat.

\section{Metode}

Jenis penelitian yang akan digunakan dalam penelitian ini adalah penelitian tindakan kelas (classroom action research). "Penelitian tindakan kelas didefinisikan sebagai suatu bentuk penelitian yang bersifat refletif dengan melakukan tindakan-tindakan tertentu agar dapat memperbaiki dan atau meningkatkan praktek-praktek pembelajaran di kelas secara lebih profesional" (Kanca, 2010:108).

Kanca, I Nyoman, 2010 menjelaskan, Tujuan PTK adalah untuk meningkatkan dan atau perbaikan praktek pembelajaran yang seharusnya dilakukan oleh guru. PTK merupakan salah satu cara yang strategis bagi guru untuk meningkatkan dan atau memperbaiki layanan pendidikan bagi guru dan dalam konteks pembelajaran dikelas. Dasar utama bagi dilaksanakannya PTK adalah untuk perbaikan kata perbaikan disini terkait dan memiliki konteks dengan proses pembelajaran. Borg (dalam Kanca, I Nyoman,2010:110) menyatakan, Bahwa tujuan utama dalam PTK sebagai pengembangan keterampilan guru berdasarkan pada persoalanan-persoalan pembelajaran yang dihadapi oleh guru di kelasnya sendiri, dan bukannya bertujuan untuk pencapaian pengetahuan umum dalam bidang pendidikan. "Terdapat empat bentuk penelitian tindakan kelas, yaitu sebagai berikut a. guru sebagai peneliti, b. penelitian tindakan kolaboratif, c. simultan terintegrasi d.adminitrasi sosial eksperimental" Oja SN dalam (Kanca I Nyoman, 2010: 115)

Penelitian ini termasuk ke dalam penelitian tindakan kelas (PTK). Penelitian tindakan kelas menurut Burns (dalam Tambolon, 2014: 16) adalah penerapan penemuan fakta dan data atas pemecahan masalah dalam situasi sosial demi meningkatkan kualitas tindakan yang dilakukan di dalamnya, yang melibatkan kolaborator dan kerjasama para peneliti, praktisi, serta orang lain.

Unsur dalam PTK menurut Kunandar (2012: 45) meliputi: (1) penelitian adalah aktivitas mencermati suatu objek tertentu melalui metodologi ilmiah dengan mengumpulkan data-data dan dianalisis untuk menyelesaikan suatu masalah, (2) tindakan adalah suatu aktivitas yang sengaja dilakukan 
dengan tujuan tertentu yang berbentuk siklus kegiatan dengan tujuan untuk memperbaiki atau meningkatkan mutu atau kualitas proses belajar mengajar, (3) kelas adalah sekelompok siswa yang dalam waktu yang sama menerima pelajaran yang sama dari seseorang guru.

Dalam penelitian ini, menurut Arikunto (2010) ada empat langkah pelaksanaan PTK, yaitu perencanaan, pelaksanaan tindakan, observasi dan evaluasi dilanjukan dengan tahap refleksi. Penelitian ini melibatkan kerja kolaborasi antara guru PJOK kelas XI AKUN, melibatkan partisipasi peserta didik kelas XI AKUN SMK Negeri 1 Singaraja tahun pelajaran 2017/2018 jumlah peserta didik 28 orang yang terdiri dari 12 orang peserta didik putra dan 16 orang siswi putri. Berdasarkan observasi awal di SMK Negeri 1 Singaraja dengan jumlah peserta didik 28 orang, peneliti mengamati bahwa dalam pembelajaran masih menggunakan metode pembelajaran yang kurang efektif. Sehingga kebanyakan peserta didik kurang aktif dalam mengikuti kegiatan pembelajaran dan hasilnya sebagian besar peserta didik tidak dapat melakukangerakan dengan teknik yang benar atau dapat dikatakan aktivitas dan hasil belajar peserta didik secara keseluruhan masih tergolong rendah. Rancangan penelitian adalah "rencana tentang bagaimana cara mengumpulkan, menyajikan, dan menganalisa data untuk memberi arti terhadap data tersebut secara efektif dan efisien" (Kanca, 2010:55). Rancangan penelitian yang digunakan dalam penelitian ini adalah penelitian tindakan kelas. Penelitian tindakan kelas adalah "suatu bentuk penelitian yang bersifat reflektif dengan melakukan tindakan-tindakan tertentu agar dapat memperbaiki dan meningkatkan praktik-praktik pembelajaran di kelas secara professional" (Kanca, 2010:108).

Penelitian ini, menggunakan 2 siklus, dimana masing- masing siklus terdiri dari 2 kali pertemuan dengan masing-masing siklus terdiri dari empat tahapan yaitu: (a) rencana tindakan, (b) pelaksanaan tindakan,(c) observasi atau evaluasi dan (d) refleksi.

Sesuai dengan karakteristik PTK, Maka masalah penelitian dalam PTK bersumber dari masalah yang muncul dalam pembelajaran di kelas.Dengan demikian indentifikasi masalah dalam PTK harus bersumber pada kondisi obyektif yang terdapat dalam kelas. Beberapa hal yang perlu diperhatikan guru dalam mengidentifikasi masalah antara lain: a) Cermati dan rasakan hal apa atau hal mana yang merupakan masalah nyata yang muncul dalam pembelajaran di kelas, b) Bedakan mana yang merupakan masalah individu, masalah beberapa orang peserta didik, dan maslah yang dialami di kelas. Masalah yang tepat untuk ditetapkan sebagai masalah PTK adalah masalah yang dirasakan oleh kelas, c) Diskusikan atau konsultasikan dengan guru lain atau pakar pendidikan jika mengalami kesulitan dalam mengidentifikasi masalah. Membimbing kelompok bekerja dan belajar terdiri dari 4 tahapan yaitu 1) Menyampaikan pertanyaan atau isu (Think), peneliti mengajukan suatu pertanyaan atau masalah yang dikaitkan dengan materi pelajaran, dan meminta peserta didik menggunakan waktu beberapa menit untuk berpikir sendiri jawabannya atau masalahnya. 2) Pembentukan pasangan (Pair) dan kelompok belajar hal yang dilakukan adalah a) Peserta didik dikelompokkan menjadi 4 kelompok dimana kelompok tersebut terdiri dari 7 orang, b) Peneliti meminta peserta didik untuk belajar secara berpasangan (pair) untuk berdiskusi tentang pertanyaan dari materi yang dipelajari, 3) Sharing dalam kelompok pasangan dan evaluasi, a) Tiap-tiap individu dalam kelompok pasangan peserta didik melakukan sharing dan sekaligus mempresentasikan materi yang dipelajari, b) Peneliti menilai setiap peserta didik dalam kelompok, sementara kelompok lain tetap belajar. 4) Evaluasi, Peneliti mengevaluasi hasil belajar tentang materi yang telah dipelajari kemudian masing-masing kelompok mempresentasikan hasil kerjanya. 5) Pemberian penghargaan, peneliti memberikan penghargaan berupa sanjungan dan tepuk tangan kepada kelompok pasangan yang paling aktif, produktif, dan memberikan pandangan yang benar.

\section{Hasil dan Pembahasan}

Pada tahap pra tindakan, peneliti memberikan tes awal dengan materi hubungan antar sudut sebagai pra syarat dari materi yang diteliti. Hal ini sesuai dengan pendapat Sutrisno (2012) yang menyatakan bahwa pelaksanaan tes sebelum perlakuan dilakukan untuk mengetahui pemahaman awal siswa. Pelaksanaan tindakan pada siklus I dan siklus II dilakukan dengan model kooperatif tipe TPS dengan tiga tahap, yaitu tahap think, tahap pair, dan tahap share pada kegiatan inti. Sebagaimana dengan yang dikemukakan oleh Arends (Patrianto, 2013) yaitu tahap think, tahap pair, dan tahap share dilaksanakan pada kegiatan inti pembelajaran. Peneliti memberikan apersepsi dengan mengingatkan kembali pengetahuan prasyarat siswa dan memberikan penguatan terhadap pengetahuan prasyarat siswa. Hal ini sejalan dengan pendapat Ningsih (2013) yang menyatakan bahwa kegiatan memberikan apersepsi adalah kegiatan yang dilakukan oleh guru untuk menciptakan suasana siap mental dan menimbulkan perhatian siswa agar terpusat pada hal-hal yang akan dipelajari.

Penelitian ini dilaksanakan dalam 2 siklus. Siklus I dilaksanakan untuk meningkatkan aktivitas dan hasil belajar teknik dasar chest pass bola basket yang dilaksanakan sebanyak 2 kali pertemuan, yaitu pada hari Kamis, tanggal 14 September 2017 memberikan tindakan dan observasi aktivitas belajar siklus I 
dengan materi chest pass bola basket. Pelaksanaan siklus II hampir sama dengan pelaksanaan siklus I. Perbedaannya pada temuan kekurangan berdasarkan hasil reflekasi pada siklus I akan diperbaiki dan dilengkapi pada siklus II. Hasil analisis data observasi awal hasil belajar pada aspek keterampian materi chest pass pada peserta didik kelas XI TN B SMK Negeri 1 Singaraja yaitu, peserta didik yang berada dalam kategori sangat baik 18 orang (56.3\%), kategori baik 3 orang (9.4\%), kategori cukup 1 orang (3\%), peserta didik yang berada dalam kategori kurang 10 (31.3\%).

Dengan hal ini, maka diketahui ketuntasan hasil belajar kompetensi keterampilan chest pass peserta didik secara klasikal yaitu sebesar 68.8\%. Hasil belajar kompetensi pengetahuan dikatakan berhasil atau tuntas secara klasikal apabila telah memenuhi standar kriteria ketuntasan minimal (KKM) sekolah untuk mata pelajaran PJOK sebesar 78\%.

Dari analisis data hasil belajar teknik dasar chest pass bola basket pada siklus I terdapat 22 orang yang tidak tuntas. Adapun masalah yang dihadapi peserta didik, antara lain : sikap yang ditunjukkan peserta didik dalam pembelajaran masih belum maksimal, dan kurangnya penguasaan gerakan teknik dasar chest pass bola basket. Tindakan-tindakan yang dilakukan untuk mengatasi permasalahan tersebut adalah : lebih menekankan kepada peserta didik tentang materi teknik dasar chest pass bola basket dari sikap, gerak pelaksanaan, dan sikap akhir, memperkecil jumlah anggota dalam satu kelompok sehingga diharapkan dengan jumlah kelompok yang kecil maka proses pembelajaran dapat berjalan lebih efektif.

Dilihat dari analisis data di atas, maka dapat disimpulkan bahwa persentase ketuntasan hasil belajar teknik dasar chest pass bola basket pada siklus I adalah 68.8\%. Dengan tercapainya hasil belajar peserta didik tersebut maka penelitian ini akan dilanjutkan ke siklus II dengan melihat kekurangan dan permasalahan pada siklus I. Permasalahan yang ditemukan adalah:peserta didik belum mengamati guru dalam mendemonstrasikan teknik dasar chest pass bola basket, peserta didik belum berani mengemukakan pendapat serta memberikan saran dalam diskusi, peserta didik belum melakukan percobaan gerakan-gerakan baru untuk membatu menyempurnakan gerakan dan peserta didik belum percaya diri dalam menghadapi serta memecahkan masalah.

Pada siklus II, dari 32 orang siswa kelas XI TN B SMK Negeri 1 Singaraja yang mengikuti pembelajaran keterampilan chest pass bola basket 18 orang peserta didik $(56.2 \%)$ dengan kategori sangat baik, 1 orang peserta didik (3.2\%) dengan kategori baik, 13 orang peserta didik (40.6\%) dengan kategori cukup tidak ada (0\%) dengan kategori kurang. Dilihat dari analisis data di atas, maka dapat disimpulkan bahwa persentase ketuntasan hasil belajar teknik dasar chest pass bola basket pada siklus II adalah $100 \%$. Bila dikonversikan kedalam persentase standar ketuntasan secara klasikal yang berlaku di SMK N 1 Singaraja yaitu 78\% untuk mata pelajaran PJOK, maka nilai ketuntasan belajar siklus II pada aspek keterampilan ini sudah tergolong tuntas. Berdasarkan hasil observasi dan evaluasi diketahui hasil belajar peserta didik pada siklus I dapat dipaparkan bahwa, peserta didik yang tuntas pada aspek pengetahuan sebanyak 8 orang (78.1\%) dan peserta didik yang tidak tuntas sebanyak 7 orang (21\%). Adapun rinciannya sebagai berikut : 8 peserta didik (25\%) dengan kategori sangat baik, 11 peserta didik (34.3\%) dengan kategori baik, 6 peserta didik (18.8\%) dengan kategori cukup, 7 peserta didik (21.9\%) dengan kategori kurang, dan tidak ada peserta didik (0\%) dengan kategori sangat kurang. Jadi hasil belajar aspek keterampilan secara klasikal pada siklus I ini sudah memenuhi KKM dari SMA Negeri 2 Singaraja, namun secara individu masih ada 7 peserta didik yang belum tuntas.

Sedangkan peserta didik yang tuntas pada aspek keterampilan sebanyak 22 orang (68.7\%) dan peserta didik yang tidak tuntas sebanyak 10 orang (31.3\%). Adapun rinciannya sebagai berikut: peserta didik dengan kategori sangat baik 18 peserta didik (56.3\%) dengan kategori sangat baik, 3 peserta didik (9.4\%) dengan kategori baik, 4 peserta didik (11,1\%) dengan kategori cukup, 10 peserta didik dengan kategori kurang. Jadi hasil belajar aspek keterampilan secara klasikal pada siklus I ini sudah memenuhi KKM dari SMK Negeri 1 Singaraja, namun secara individu masih ada 10 peserta didik yang belum tuntas.

Berdasarkan hasil observasi dan evaluasi diketahui hasil belajar peserta didik pada siklus II dapat dipaparkan bahwa, peserta didik yang tuntas pada aspek pengetahuan sebanyak 32 orang (100\%) dan tidak ada peserta didik yang tidak tuntas. Adapun rinciannya sebagai berikut : 11 peserta didik (34.4\%) dengan kategori sangat baik, 19 peserta didik (59.4) dengan kategori baik, 2 peserta didik (6.2\%) dengan kategori cukup, dan tidak ada peserta didik (0\%) dengan kategori kurang. Jadi hasil belajar aspek pengetahuan secara klasikal pada siklus II ini sudah memenuhi KKM dari SMK Negeri 1 Singaraja dan seluruh siswa terkategori tuntas. Sedangkan peserta didik yang tuntas pada aspek keterampilan sebanyak 32 orang $(100 \%)$ dan tidak ada peserta didik yang tidak tuntas. Adapun rinciannya sebagai berikut : 18 peserta didik (56.2) dengan kategori sangat baik, 1 peserta didik (3.2\%) dengan kategori baik, 13 peserta didik (40.6\%) dengan kategori cukup, tidak ada peserta didik dengan kategori kurang. Jadi hasil belajar aspek keterampilan secara klasikal pada siklus I ini sudah memenuhi KKM dari SMK Negeri 1 Singaraja, dan secara individu sudak terkategori tuntas. 
Hal ini juga sejalan dengan penelitian yang dilakukan oleh Jasdilla (2016) yang menyatakan bahwa model pembelajaran kooperatif tipe Think, Pair, Share (TPS) dapat meningkatkan hasil belajar IPS di kelas IV sekolah dasar. Dengan dihargainya setiap pendapat keberanian siswa mulai tumbuh untuk terbiasa berpendapat dan memberikan sumbangan pikirannya tidak hanya untuk dirinya sendiri tapi juga untuk rekan atau teman-temannya; (3) Siswa mulai disiplin dalam mengerjakan tugas dengan waktu yang telah diberikan sehingga kegiatan pembelajaran berlangsung aman dan kondusif. Hal ini disebabkan mulai sadarnya siswa akan sikap tidak disiplin yang juga merugikan dirinya sendiri. Penerapan model pembelajaran TPS ini secara tidak langsung melatih siswa untuk menumbuhkan rasa percaya dirinya serta mengembangkan kemampuannya dalam berbagi informasi dan menyampaikan pendapat serta mengemukakan ide yang mereka miliki, yang menyebabkan suasana kelas menjadi kondusif dan menyenangkan. Hal ini sejalan dengan hasil peneitian yang dilakukan oleh Widiana ( 2014) disimpulkan bahwa penerapan model pembelajaran kooperatif tipe think pair square berpengaruh positif terhadap hasil belajar Matematika siswa kelas V di Gugus I Nakula Kecamatan Negara. Model pembelajaran ini juga membantu siswa untuk pemahaman konsep dan materi pelajaran dan menggali kemampuan dalam hal informasi dan pengetahuan yang dimilikinya secara mandiri dan berpasangan. Selain itu Ermawan (2014) dan Adnyana (2016 menyatakan bahwa model pembelajaran kooperatif tipe TPS karena dapat meningkatkan aktivitas dan hasil belajar.

\section{Simpulan dan Saran}

Berdasarkan hasil analisis data dan pembahasan, dapat disimpulkan hal-hal sebagai berikut, pengetahuan aktivitas dan keterampilan gerak chest pass dalam permainan bola basket meningkat melalui implementasi model pembelajaran kooperatif tipe TPS pada peserta didik kelas XI TN B SMK Negeri 1 Singaraja.

Diharapkan kepada peserta didik yang dijadikan subjek penelitian selanjutnya lebih memperhatikan dan memahami pembelajaran yang diberikan, agar dapat menambah paradigma maupun wawasan pengetahuan khususnya dalam pembelajaran materi teknik dasar chest pass bola basket maupun pada pembelajaran yang lain. Disarankan kepada guru pendidikan jasmani, olahraga dan kesehatan agar menerapkan model pembelajaran kooperatif tipe Think Pair Share (TPS), karena terbukti dapat meningkatkan aktivitas dan hasil belajar teknik dasar chest pass bola basket.

\section{Daftar Rujukan}

Adnyana, I Komang Ngurah, I Nyoman Kanca, Adnyana Putra. 2016. Implementasi Model Pembelajaran Kooperatif Tps Meningkatkan Aktivitas Dan Hasil Belajar Passing Bola Basket. e-Journal PJKR Universitas Pendidikan Ganesha Jurusan Pendidikan Jasmani, Kesehatan, dan Rekreasi Vol 5, No 2.

Arikunto, Suhadjono, dan Supardi. 2008. Penelitian Tindakan Kelas. Jakarta: PT Bumi Aksara.

Budiarta, I Nyoman Adi. 2014. Implementasi Kooperatif Tps Untuk Meningkatkan Aktivitas Dan Hasil Belajar Passing Bola Basket. E-Journal Universitas Pendidikan Ganesha.

Dimyati dan Mudjono dan Mudjiono. 2006. Belajar dan Pembelajaran. Jakarta: Rineka Cipta.

Ermawan, Gede, I Made Danu Budhiarta, Made Kurnia Widiastuti Giri. 2014. Penerapan Model Kooperatif Tps Untuk Meningkatkan Aktivitas Dan Hasil Belajar Passing Bola Basket. e-Journal PJKR Universitas Pendidikan Ganesha Jurusan Pendidikan Jasmani Kesehatan dan Rekreasi Vol. 2, No.1.

Isjoni. 2013. Cooperative Learning. Bandung: Alfabeta.

Jasdilla. 2016. Hasil Belajar Dan Pembelajaran Kooperatif Tipe Think Pair Share (Tps). Journal Pendidikan Indonesia P-ISSN: 2303288X E-ISSN: 2541-7207 Vol. 6, No.1, April 2016. http://ejournal.undiksha.ac.id/index.p hp/JPI/article/view/9253/6328

Jaya, I Kadek Arsa, I Ketut Budaya Astra, Ni Nyoman Mestri Agustini . 2014. Implementasi Model Pembelajaran Kooperatif Tps Untuk Meningkatkan Aktivitas Dan Hasil Passing Bola Voli. EJournal PJKR Universitas Pendidikan Ganesha Jurusan Pendidikan Jasmani Kesehatan dan Rekreasi Vol 2. 
Junaedi, dkk. 2008. Strategi Pembelajaran. Edisi Pertama. Surabaya: LAPIS-PGMI

Kanca. 2010. Metode Penelitian dan Pengajaran Pendidikan Jasmani dan Olahraga. Singaraja Universitas Pendidikan Ganesha.

Kementerian Pendidikan dan Kebudayaan. 2014. Buku Guru Pendidikan Jasmani Olahraga dan Kesehatan SMA/MA, SMK/MA Kelas XI. Cetakan Ke-1. Jakarta: Kementerian Pendidikan dan Kebudayaan.

Kunandar. 2007. Implementasi kurikulum tingkat satuan pendidikan kemandirian guru dan kepala sekolah. Jakarta: Bumi Aksara.

Kurniasih, Imas \& Berlin Sani.2016. Ragam Pengembangan Model Pembelajaran Untuk Peningkatan Profesionalitas Guru.Jogjakarta: Kata Pena.

Ni'mah, A ., P. Dwijananti . 2014. Penerapan Model Pembelajaran Think Pair Share (Tps) Dengan Metode Eksperimen Untuk Meningkatkan Hasil Belajar Dan Aktivitas Belajar Siswa Kelas VIII MTS. Nahdlatul Muslimin Kudus. Unnes Physics Education Journal, UPEJ 3 (2).

Ningsih. (2013). Perbedaan Pengaruh Pemberian Apersepsi Terhadap Kesiapan Belajar Siswa Mata Pelajaran IPS Kelas VII A. Dalam Jurnal Untan [Online]. 11 halaman. Tersedia: http://jurnal.untan.ac.id/ index.php/jpdpb/article/down load/2349/2281

Nurkancana dan Sunartana. 1992. Evaluasi Hasil Belajar. Surabaya: Usaha Nasional.

Oktavianto, Mohammad Yoby Pradana, Sutardji, Taufiq Hidayah. 2012. Sumbangan Power Lengan Dan Panjang Lengan Terhadap Kemampuan Lempar Chest Pass Bola Basket Pada Klub Bola Basket Bluesky Kabupaten Demak. Journal of Sport Sciences and Fitness, JSSF 1 (2).

Patrianto, U. 2013. Penerapan Model Pembelajaran Kooperatif Tipe Think Pair Share Untuk Memahamkan Materi Logaritma Kelas X SMKN 5 Malang. Jurnal [Online]. Tersedia:http://jurnalonline.um.ac.id/data/artikel/artikelFF78F36ADF773C18270482 4E300C97F7. pdf [15 februari 2014].

Sutrisno. 2012. Efektivitas Pembelajaran dengan Metode Penemuan Terbimbing Terhadap Pemahaman Konsep Matematis Siswa. Dalam Jurnal Pendidikan Matematika [online]. Vol 1 (4), 16 halaman. Tersedia:http://fkip.unila.ac.id/ojs/journals /II/JPMUVol1No4/016 -Sutrisno.pdf [19 September 2014].

Tawil, Akhyar H. M. 2014. Penerapan Pendekatan Scientific Pada Model Pembelajaran Kooperatif Tipe Think Pair Share Untuk Meningkatkan Pemahaman Siswa Di Kelas Vii Smpn 6 Palu. Jurnal Elektronik Pendidikan Matematika Tadulako, Volume 2 Nomor 1.

Thobroni, Muhammad \& Arif Mustofa. 2011. Belajar dan Pembelajaran. Yogyakarta : Ar-Ruzz Media.

Trianto. 2007. Model-Model Pembelajaran Inovatif. Jakarta: Prestasi Pustaka Publisher.

Trianto. 2009. Mendesain Model Pembelajaran Inovatif-Progresif. Jakarta : Kencana.

www.tutorialolahraga.com/2015

http://el1ardiani.wordpress.com/2010/10/teknik-chest-pass-b0la-basket.html

http://id.shvoong.com/social-sciences/education/2009902-strategi-pembelajaran-kooperatif-spk/

Widiana, dkk. 2014. Pengaruh Model Pembelajaran Kooperatif Tipe Think Pair Square (Tps) Berbantuan Kartu Kerja Terhadap Hasil Belajar Matematika. Jurnal Mimbar PGSD Universitas Pendidikan Ganesha Jurusan PGSD (Vol: 2 No: 1 Tahun 2014) 
Widiana. 2016. Pengembangan Pembelajaran Berbasis Otak Dalam Pembelajaran Matematika Untuk Meningkatkan Kemampuan Berpikir Kritis. Artikel. e-Journal PGSD Universitas Pendidikan Ganesha Jurusan PGSD Vol: 4 No: 1 Tahun: 2016. http://ejournal.undiksha.ac.id/inde x.php/JPGSD/article/view/7690/5242

Widiana, I Wayan, Gede Wira Bayu, I Nyoman Laba Jayata. 2017. Pembelajaran Berbasis Otak (Brain Based Learning), Gaya Kognitif Kemampuan Berpikir Kreatif Dan Hasil Belajar Mahasiswa. Jurnal Pendidikan Indonesia Universitas Pendidikan Ganesha. Vol 6 No 1.

Widiaastuti dan Ali K. tt. Grand Kamus Inggris-Indonesia Indonesia- Inggris. Surabaya: Apollo.

Winantara, I.W. Daniel. 2017. Penerapan Model Pembelajaran Tps Untuk Meningkatkan Hasil Belajar Ipa Siswa Kelas V Sd No 1 Mengwitani. Journal of Education Action Research Universitas Pendidikan Ganesha, Volume 1 No. 2.

Wena, Made. 2009. Strategi Pembelajaran Inovatif Kontemporer: Suatu Pendekatan Konseptual Operasional. Jakarta: Bumi Aksara. 